\title{
Westerners Underestimate Global Inequality
}

\author{
Ignazio Ziano \\ Ignazio.ziano@grenoble-em.com \\ Department of Marketing \\ Grenoble Ecole de Management \\ Ivuoma Ngozi Onyeador \\ (ivy.onyeador@kellogg.northwestern.edu) \\ Department of Management and Organizations \\ Kellogg School of Management \\ Northwestern University
}

This version: December $23^{\text {rd }}, 2021$. This paper is under review. 


\begin{abstract}
Most global inequality is between-countries, but inequality perceptions have mostly been investigated within-country. Five studies (total $\mathrm{N}=2149$, four preregistered) show that Westerners (U.S. American, British, and French participants) believe that developing and middle-income countries' GDP per capita is much closer to developed countries' than it actually is, and that people in developing and middle-income countries have higher rates of car ownership, larger houses, and eat out more frequently than they actually do, meaning that Westerners underestimate global inequality. This misperception is underpinned by a convergence illusion: the belief that since the 1990s, poorer countries have closed the economic gap with richer countries to a larger extent than they have. Further, overestimating GDP per capita is negatively correlated with support for aid to the target country and positively correlated with a country's perceived military threat. We discuss implications for inequality perception and for global economic justice.
\end{abstract}




\section{Westerners Underestimate Global Inequality}

“[...] we will lift Shanghai up and up, ever up, until it is just like Kansas City."

- Kenneth Wherry, U.S. Senator for Nebraska, 1940

The economic gap between rich and poor countries is staggering. The most unequal country in the world is South Africa, with an income-inequality Gini index of 0.63 (World Bank, 2021); recent estimates of global income inequality also showed a Gini index of 0.63 (Milanovic, 2021), which makes the world as unequal as the most unequal country in it. However, we know little about perceptions of global inequality, as research about inequality perceptions has usually investigated within-country inequality (e.g., Niehues, 2014; Norton \& Ariely, 2011). The present article shows that Westerners overestimate how rich developing and middle-income countries are, meaning that Westerners underestimate global inequality. They seem to think that Senator Wherry's dream is much closer to reality than it actually is.

\section{Inequality perceptions}

A large literature investigates estimates of income inequality in a single country and finds that people largely misperceive inequality. In the USA, people either underestimate inequality (Norton \& Ariely, 2011) or they overestimate it (Chambers et al., 2014; Eriksson \& Simpson, 2013). This literature also investigates the racial wealth gap within the USA, showing that U.S. Americans vastly underestimate inequality between Black and White Americans (Kraus et al., 2017), a misconception that proves difficult to correct (Callaghan et al., 2021; Kraus et al., 2020; Onyeador et al., 2021). This is not unique to the U.S.; other North Americans, South Americans, and Europeans misperceive inequality in their own countries (Cruces et al., 2013; Fernández-Albertos \& Kuo, 2015; Niehues, 2014). In fact, people all over the world seem to perceive inequality incorrectly, over- or underestimating it depending on how it is measured (Gimpelson \& Treisman, 2018). A common thread in this 
research is that - even when the participants came from several countries (as in Niehues, 2014) - all participants misperceived inequality in the country in which they lived. Little work has explored perceptions of inequality between countries. Our research takes a first step towards filling this gap by focusing on perceptions of global inequality.

In addition, estimations of other countries' income may also be associated with political attitudes towards them. For instance, perceptions of inequality are associated with favouring redistribution (Niehues, 2014), so it follows that, the larger the overestimation of another country's economic standing, the less people may be in favour of sending it economic aid. Gross Domestic Product (GDP) is positively correlated with military spending, as richer countries have more money to spend on defense. It is therefore possible that the more people overestimate how rich a certain country is, the more they perceive it as a military threat. Finally, people tend to migrate from poorer to richer countries. Thus, it is possible that citizens of rich countries overestimate the economic standing of poorer countries, and that such overestimation would be negatively correlated with attitudes towards migration from the target country to a given richer country.

\section{Study overview}

We conducted five studies (total $\mathrm{N}=2149$, four preregistered; summarized in Table 1) with U.S. American, British, and French participants. Study 1 tested U.S. Americans' perceptions about developing and middle-income countries rates of car ownership, house size, and weekly frequency of dining out, both in absolute and comparative estimation. Study 2 tested whether U.S. Americans believe that GDP per capita in developing and middleincome countries is closer to the U.S.A.'s than it actually is. Study 3 and Study 4 investigate the possibility of a convergence illusion, testing French and British participants estimates of the economic gap between richer and poorer countries over the past few decades. Study 5 tests whether overestimates of the economic standing of poor and middle-income countries 
are correlated with attitudes towards aid, perceived military threat, and attitudes towards immigration from these countries. Data, analyses and materials are available at https://osf.io/mzeqd/?view_only=73f06a5b5718421b972f06a715acc9c3.

Table 1

Study overview

\begin{tabular}{lll}
\hline Study & $\begin{array}{l}\text { Sample (participants' } \\
\text { country of residence) }\end{array}$ & Main result \\
\hline Study 1 & 408 (U.S.A) & $\begin{array}{l}\text { U.S. American participants overestimate car } \\
\text { ownership rates, rooms per person, and frequency } \\
\text { of eating out in developing and middle-income } \\
\text { countries }\end{array}$ \\
Study 2 & 784 (U.S.A.) & $\begin{array}{l}\text { U.S. American participants overestimate the GDP } \\
\text { per capita of developing and middle-income } \\
\text { countries }\end{array}$ \\
Study 3 & 170 (France) & $\begin{array}{l}\text { French participants overestimate the GDP per } \\
\text { capita of developing and middle-income countries; } \\
\text { believe that these countries have gotten closer to }\end{array}$ \\
& 389 (U.K.) & $\begin{array}{l}\text { France over time } \\
\text { British participants overestimate the GDP per } \\
\text { capita of developing and middle-income countries; } \\
\text { believe that these countries have gotten closer to } \\
\text { the UK over time } \\
\text { U.S. American participants' GDP per capita } \\
\text { overestimation is negatively correlated with } \\
\text { support for aid, and positively correlated with } \\
\text { perceived military threat. }\end{array}$ \\
\hline Study 5 & 399 (U.S.A.) &
\end{tabular}

Methods and Results

Study 1 - U.S. American overestimate Car-ownership rates, Rooms per Person, and Frequency of Dining Out in Poorer Countries

The objective of this study is to test whether people overestimate various measures of wealth, in several developing and middle-income countries, both in absolute terms and compared to the USA. This study was preregistered at https://aspredicted.org/RY2_DG2.

Participants. We recruited 408 U.S. American participants from Prolific, who were paid $£ 0.60$ for this task. Three participants failed the attention check by replying "Yes" to the 
question "Have you ever been on the planet Mars" and were excluded from analyses, as preregistered. This exclusion left 405 valid participants (195 men, 202 women, 8 nonbinary people; $M_{\text {age }}=32.74, \mathrm{SD}=12.49 ; 281$ Caucasian, 36 Black, 37 Asian, 38 Hispanic, 1 Native American, 9 Two or more races, 3 no response).

Procedure. Participants were asked to make a series of estimates about the proportion of households who own a car (in China, India, Mexico, and Turkey); the number of people per room (in Brazil, Mexico, Russia, and Turkey); and the number of times per week in which people eat out, on average (in China, India, Indonesia, and Russia). We chose these indicators because they are correlated with economic activity and income in a country (Bren d'Amour et al., 2020; Nolan, 2010; OECD, 2021) and they could be compared with the actual values as collected in international surveys (Kantar, 2021; OECD, 2021; Pew Research Center, 2015). Participants were randomly assigned to one of two conditions, absolute standing and comparative.

In the absolute standing condition, we asked participants to estimate absolute quantities (e.g., the absolute number of times that people eat out in Indonesia on a weekly basis). In the absolute standing condition, participants estimated car ownership rate on a slider bounded at 0 and 100. Participants estimated the number of rooms per person by inputting a number between 0 and 10 (with one decimal allowed). Participants estimated the weekly frequency of meals outside of the home by entering a number from 0 to 10 in a textbox (with one decimal allowed). We chose these boundaries as they represented the absolute possible limits in the estimation of the proportion of households with a car, and reasonable upper limits in the case of the other two estimations, considering the actual values (which hover around 1 for rooms per person, and at most 2.6 for weekly meals outside the house).

In the comparative condition, we asked participants to estimate the proportion between the target country and the USA (adapting a method from Kraus et al. 2017), to gauge 
estimates of both the absolute standing of each country and the standing of each country relative to the US. In the comparative condition, participants were asked to estimate car ownership rate, rooms per person, and frequency of meals outside of the home on a slider bounded at 0 and 2, in order to compare the target country and the USA. Note that no country scored double the USA on any metric (in fact the actual proportions were all below 1). For instance, when estimating the proportion in frequency of dining out, participants were shown these instructions: "Note that 1 means that people in the target country eat out with the same frequency that they do in the USA; 2 means that people in the target country eat out with double the frequency than in the USA, and numbers lower than 1 indicate that people in the target country eat out less frequently than in the USA."

\section{Results and Discussion}

We conducted a series of one-sample t-tests against the actual value of car ownership (for instance, participants reported that they believed that $49 \%$ of households in China own a car, while the actual value is $17 \%$ ), weekly dining out frequency, and number of rooms per person, finding gross overestimation in all cases, with effect sizes ranging from medium to very large. Similarly, participants overestimated these values when they had to make a comparison between the USA and the target country (for instance, they believed that the ratio between the proportion of households with a car in China and in the USA was 0.82, while the actual value is 0.20). These results are summarized in Figure 1 and Tables 2, 3, and 4. Overall, this study shows that U.S. Americans overestimate the number of households with a working car, the number of times people eat out per week, and the number of rooms per person in poorer countries, both when they have to make estimates in absolute numbers and when they have to compare the target country to their own (the USA). 
Figure 1. Actual and estimated car ownership, rooms per person, and weekly dining out frequency, both as absolute values and compared to the USA, Study 1.

\section{Actual and estimated values}

Estimate means and $95 \%$ confidence intervals are depicted Estimates were provided by two different subsamples

\section{Proportion of households with a car}

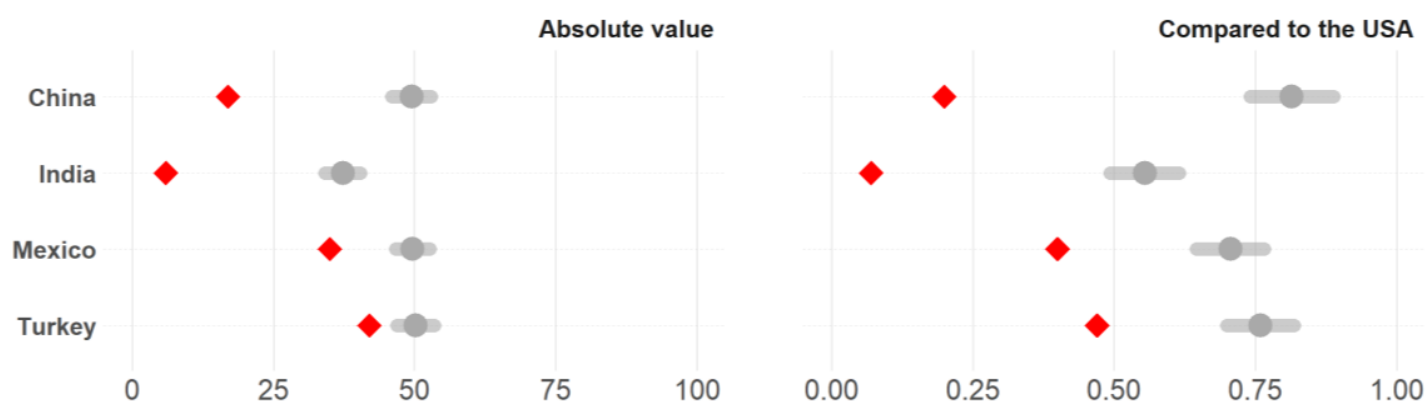

\section{Rooms per person}

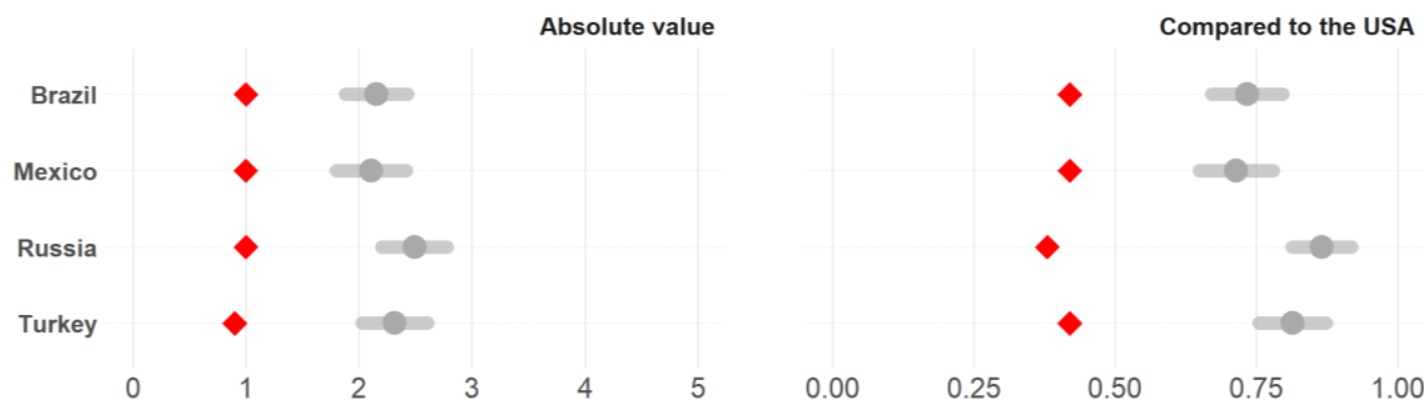

\section{Weekly dining out frequency}

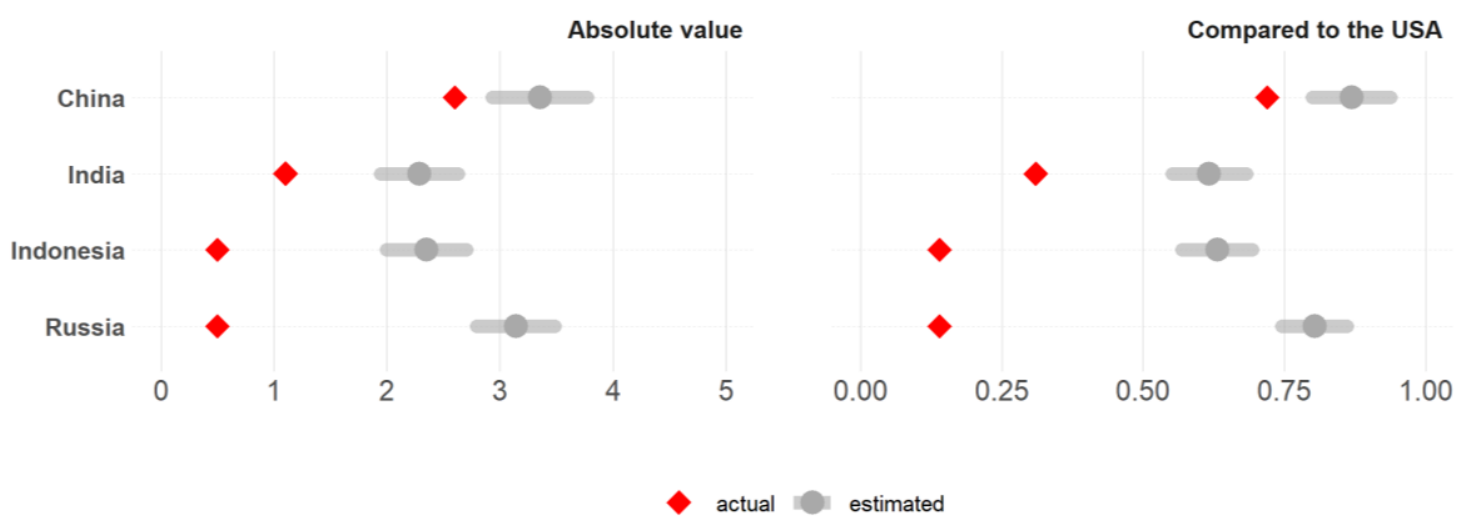


Table 2

One-sample t-test results comparing actual (Pew Research Center, 2015) and estimated car ownership, both compared to the USA and in percentage

\begin{tabular}{lllllll}
\hline \multicolumn{3}{l}{ Absolute values } & \multicolumn{3}{l}{ Compared to the USA } \\
\hline Country & $\begin{array}{l}\text { Actual } \\
\text { value }\end{array}$ & $\begin{array}{l}\text { Estimate } \\
\mathrm{M}(\mathrm{SD})\end{array}$ & Cohen's d & $\begin{array}{l}\text { Actual } \\
\text { proportion }\end{array}$ & $\begin{array}{l}\text { Estimate } \\
\mathrm{M}(\mathrm{SD})\end{array}$ & Cohen's d \\
\hline China & 17 & $\begin{array}{l}49.45 \\
(21.55)\end{array}$ & $1.51^{* * *}$ & 0.20 & $0.82(0.47)$ & $1.32^{* * * *}$ \\
India & 6 & $\begin{array}{l}37.27 \\
(19.90)\end{array}$ & $1.57^{* * *}$ & 0.07 & $0.55(0.39)$ & $1.24^{* * *}$ \\
Mexico & 35 & $\begin{array}{l}49.65 \\
(19.06)\end{array}$ & $0.77^{* * *}$ & 0.40 & $0.71(0.38)$ & $0.81^{* * * *}$ \\
Turkey & 42 & $\begin{array}{l}50.21 \\
(20.82)\end{array}$ & $0.39 * * *$ & 0.47 & $0.76(0.38)$ & $0.77^{* * *}$ \\
& & & & & \\
\hline
\end{tabular}

Note. $* * * p<.001$. The values in the comparative condition range from 0 to 2 , while the numbers in the absolute values conditions could range from 0 to 100. In the absolute condition, the actual values were drawn from research conducted by the Pew Research Center (2015). In the comparative condition, the actual values were calculated by dividing the value of the target country by the value in the USA, as presented in Pew Research Center (2015). 
Table 3

One-sample t-test results comparing actual (OECD, 2021) and estimated rooms per person, both compared to the USA and in absolute numbers

\begin{tabular}{llll|lll}
\hline \multicolumn{3}{l|}{ Absolute values } & \multicolumn{3}{l}{ Compared to the USA } \\
\hline Country & Actual value & $\begin{array}{l}\text { Estimate } \\
\text { M (SD) }\end{array}$ & Cohen's d & $\begin{array}{l}\text { Actual } \\
\text { propor } \\
\text { tion }\end{array}$ & $\begin{array}{l}\text { Estimate } \\
\text { M (SD) }\end{array}$ & Cohen's d \\
\hline Brazil & 1 & $2.15(1.70)$ & $0.68^{* * *}$ & 0.42 & $0.73(0.40)$ & $0.79 * * *$ \\
Mexico & 1 & $2.11(1.93)$ & $0.57 * * *$ & 0.42 & $0.71(0.41)$ & $0.71^{* * *}$ \\
Russia & 0.9 & $2.49(1.81)$ & $0.88^{* * *}$ & 0.38 & $0.87(0.33)$ & $1.35^{* * *}$ \\
Turkey & 1 & $2.15(1.70)$ & $0.68^{* * *}$ & 0.42 & $0.73(0.40)$ & $0.79 * * *$ \\
\hline
\end{tabular}

Note. $* * * p<.001$. The values in the comparative condition range from 0 to 2 , while the numbers in the absolute values condition range from 0 to 100. In the absolute condition, the actual values were drawn from OECD (2021). In the comparative condition, the actual values were calculated by dividing the value of the target country by the value in the USA as presented in OECD (2021). 
Table 4

One-sample t-test results comparing actual (Kantar, 2021) and estimated frequency of dining out per person, both compared to the USA and in absolute numbers

\begin{tabular}{llll|lll}
\hline \multicolumn{3}{l}{ Absolute values } & \multicolumn{3}{l}{ Compared to the USA } \\
\hline Country & $\begin{array}{l}\text { Actual } \\
\text { value }\end{array}$ & $\begin{array}{l}\text { Estimate } \\
\mathrm{M}(\mathrm{SD})\end{array}$ & Cohen's d & $\begin{array}{l}\text { Actual } \\
\text { proportion }\end{array}$ & $\begin{array}{l}\text { Estimate } \\
\mathrm{M}(\mathrm{SD})\end{array}$ & Cohen's d \\
\hline China & 2.6 & $3.35(2.62)$ & $0.29 * * *$ & 0.72 & $0.87(0.44)$ & $0.34 * * *$ \\
India & 1.1 & $2.29(2.15)$ & $0.55^{* * *}$ & 0.31 & $0.62(0.42)$ & $0.74 * * *$ \\
Indonesia & 0.5 & $2.35(2.21)$ & $0.84 * * *$ & 0.14 & $0.63(0.39)$ & $1.25 * * *$ \\
Russia & 0.5 & $3.14(2.17)$ & $1.22 * * *$ & 0.14 & $0.80(0.37)$ & $1.82^{* * *}$ \\
\hline
\end{tabular}

Note. ${ }^{* * *} p<.001$. The values in the comparative condition range from 0 to 2 , while the values in the absolute condition could range from 0 to 10 . In the absolute condition, the actual values were drawn from Kantar (2021). In the comparative condition, the actual values were calculated by dividing the value of the target country by the value in the USA as presented in Kantar (2021). 


\section{Study 2 - U.S. Americans Underestimate the Economic Difference between the USA and Poorer Countries}

The objective of this study is to test whether U.S. Americans overestimate the standing of developing and middle-income countries compared to their own country, using the proportion between GDP per capita of the target country and the USA as a measure.

\section{Methods}

Participants. We recruited 790 U.S. American participants from MTurk, who were paid $\$ 1.00$ for this task. Six participants failed the attention check by replying "Yes" to the question "Have you ever been on the planet Mars" and were excluded from analyses as preregistered. This exclusion left 784 participants (414 males, 362 females, 5 nonbinary people, 3 preferred not to disclose; $M_{\text {age }}=40.47, \mathrm{SD}=12.70$ ).

Procedure. In this study we used GDP per capita at purchasing power parity (PPP) to correct for local differences in purchasing power. This indicator it is computed and made available from the World Bank (World Bank, 2019). Participants were shown a definition of GDP per capita, at purchasing power parity (PPP). Then, they were asked to reply to three comprehension checks. Participants could not continue with the survey until they answered the comprehension checks correctly. Participants were then showed a short description of nine countries (in randomized order; Brazil, China, France, India, Mexico, Nigeria, Poland, Russia, United Kingdom) and were instructed to indicate how many dollars of GDP per capita (PPP) they thought the target country had in 2019 for every $\$ 100$ of GDP per capita (PPP) in 2019 in the USA, on a slider bounded at 0 and 200 (a method adapted from Kraus et al. 2017). For instance, when the target country was the UK, participants were asked:

For every $\$ 100$ of GDP per capita (PPP) in 2019 in the USA, how many GDP per capita (PPP) dollars do you think the United Kingdom had in 2019 ? 
Please reply on this slider. Note that 100 means that the USA and the United Kingdom had exactly the same GDP per capita (PPP) in this year.

At the end of the survey, we also measured participants' ideology on one item bounded at 1 (very liberal) and 7 (very conservative).

\section{Results and Discussion}

A series of one-sample t-tests comparing the actual and the estimated GDP per capita proportions showed overestimation across the board, and seemingly larger for developing and middle-income countries, and less so for richer countries (Table 5 and Figure 2). Ideology showed only small correlations with some of the estimations (being statistically significant only for UK and France, Pearson's $r=0.08, p=.025$ and $r=.10, p=.006$ respectively, meaning more conservative participants were more likely to overestimate; all other $r$ s $<.06$ and all other $p s>.10)$.

This study shows that U.S. Americans believe that people in other countries are much closer to U.S. levels of economic development than they actually are. This shows that U.S. Americans may have a biased view of the economic state of the world, believing that it is much more equal than it actually is. 
Figure 2. Comparing estimated and actual 2019 GDP per capita (PPP) (proportion compared to the USA), Study 2.

\section{Actual and estimated values}

2019 GDP per capita (PPP), ratio between target country and the USA Estimation means and 95\% confidence intervals are depicted

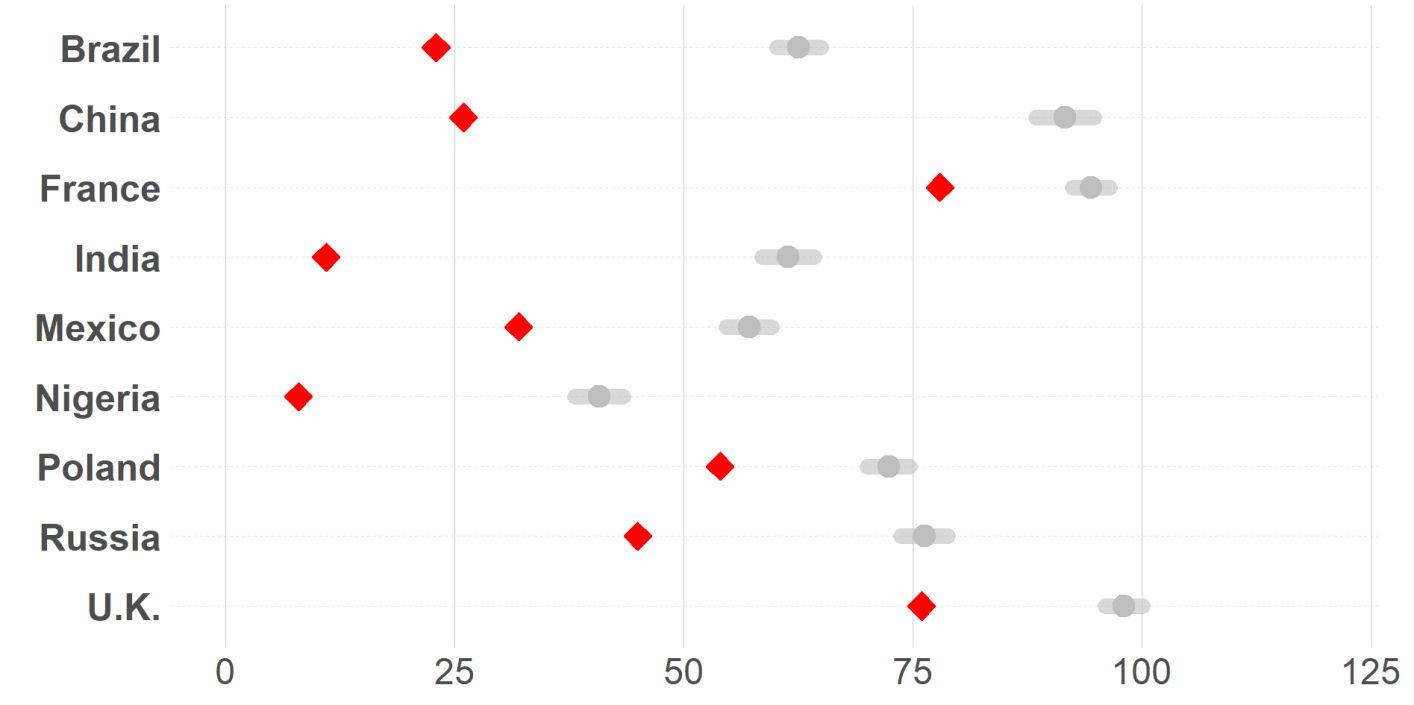


Table 5

Results of a series of one-sample t-tests comparing estimated and actual GDP per capita (PPP) in 2019 (proportion compared to the USA), Study 2

\begin{tabular}{lllll}
\hline Target country & $\begin{array}{l}\text { Actual } \\
\text { proportion }\end{array}$ & $\begin{array}{l}\text { Estimated } \\
\text { proportion } \\
\text { M (SD) }\end{array}$ & $\begin{array}{l}\text { Overestimation } \\
\text { extent* }\end{array}$ & Cohen's d \\
\hline Brazil & 23 & $62.59(32.07)$ & 40 & $1.24 * * *$ \\
China & 26 & $91.66(42.44)$ & 76 & $1.55^{* * *}$ \\
France & 78 & $94.47(27.39)$ & 16 & $0.60^{* * *}$ \\
India & 11 & $61.41(38.12)$ & 50 & $1.32^{* * *}$ \\
Mexico & 32 & $57.17(33.54)$ & 25 & $0.75 * * *$ \\
Nigeria & 8 & $40.82(35.51)$ & 32 & $0.92^{* * *}$ \\
Poland & 54 & $72.39(31.54)$ & 18 & $0.58^{* * *}$ \\
Russia & 45 & $76.30(34.36)$ & 29 & $0.91 * * *$ \\
UK & 76 & $98.06(27.17)$ & 22 & $0.81^{* * *}$ \\
\hline Note. & GDP per & (P) & & \\
\hline
\end{tabular}

Note. ${ }^{*}$ GDP per capita (PPP) in percentage points; $* * * p<.001$

Study 3 - French Students Underestimate the Economic Difference between France and Poorer Countries and Overestimate its Improvement over Time

The objective of this study was to test what French students think of the economic standing of other countries compared to France (to replicate previous results in a nonAnglophone Western population), and measure whether they believe that the gap between richer and poorer countries has closed in the past decades, and to what extent. This study was preregistered at https://aspredicted.org/blind.php? $\mathrm{x}=24 \mathrm{hs} 2 \mathrm{u}$.

\section{Methods}

Participants and attention checks. We recruited 170 participants (66 males, 103 females, 1 other, $M_{\text {age }}=22.61, S D_{\text {age }}=6.07 ; 142$ of French nationality) from a French 
business school, who participated for course credit. None failed the attention check, therefore we retained all of them for analyses.

Procedure. Participants were first provided with a definition of GDP per capita (PPP). Then, participants were presented with three comprehensions checks, which they had to correctly answer in order to proceed with the survey.

Measures. Participants were shown seven countries in randomized order (China, India, Mexico, Nigeria, Poland, UK, and USA). For each country, they were asked to estimate the proportion of GDP per capita (PPP) between France and the country, in $1979^{1}, 1999$, and 2019 on a slider bounded at 0 and 200, using a method similar to the one used in Study 2.

\section{Results and Discussion}

A series of one-sample t-tests comparing the actual and the estimated GDP per capita proportions showed overestimation across the board, and seemingly larger for developing and middle-income countries compared to richer countries (Figure 3 and Table 6). These results replicate the results of Study 1 and 2 with participants from a different Western country. While participants had a broadly correct view of the rank-order of countries (e.g., they seemed to know that China is richer than India, and that India is richer than Nigeria, but there were exceptions regarding Poland and Mexico), there seems to be massive overestimation of the economic standing of countries poorer than France. Specifically, the case of China stands out, as participants believed that in 2019, China's GDP per capita was basically on the same level as France's. Further, it seems that participants believe that poorer countries have been "catching up" with richer ones to a larger extent than they actually are (if at all), as evidenced by the increase in all the estimated values in 1999 and in 2019.

\footnotetext{
${ }^{1}$ In the analyses, we did not use the 1979 datapoint as the World Bank database does not contain GDP per capita (PPP) before 1990.
} 
Figure 3. Real and estimate GDP per capita (PPP) of seven countries in proportion with France's GDP per capita (PPP), in 1999 and 2019, Study 3.

\section{Actual and estimated ratios...}

GDP per capita (PPP), ratio between target country and France in given year Estimation means and 95\% confidence intervals are depicted

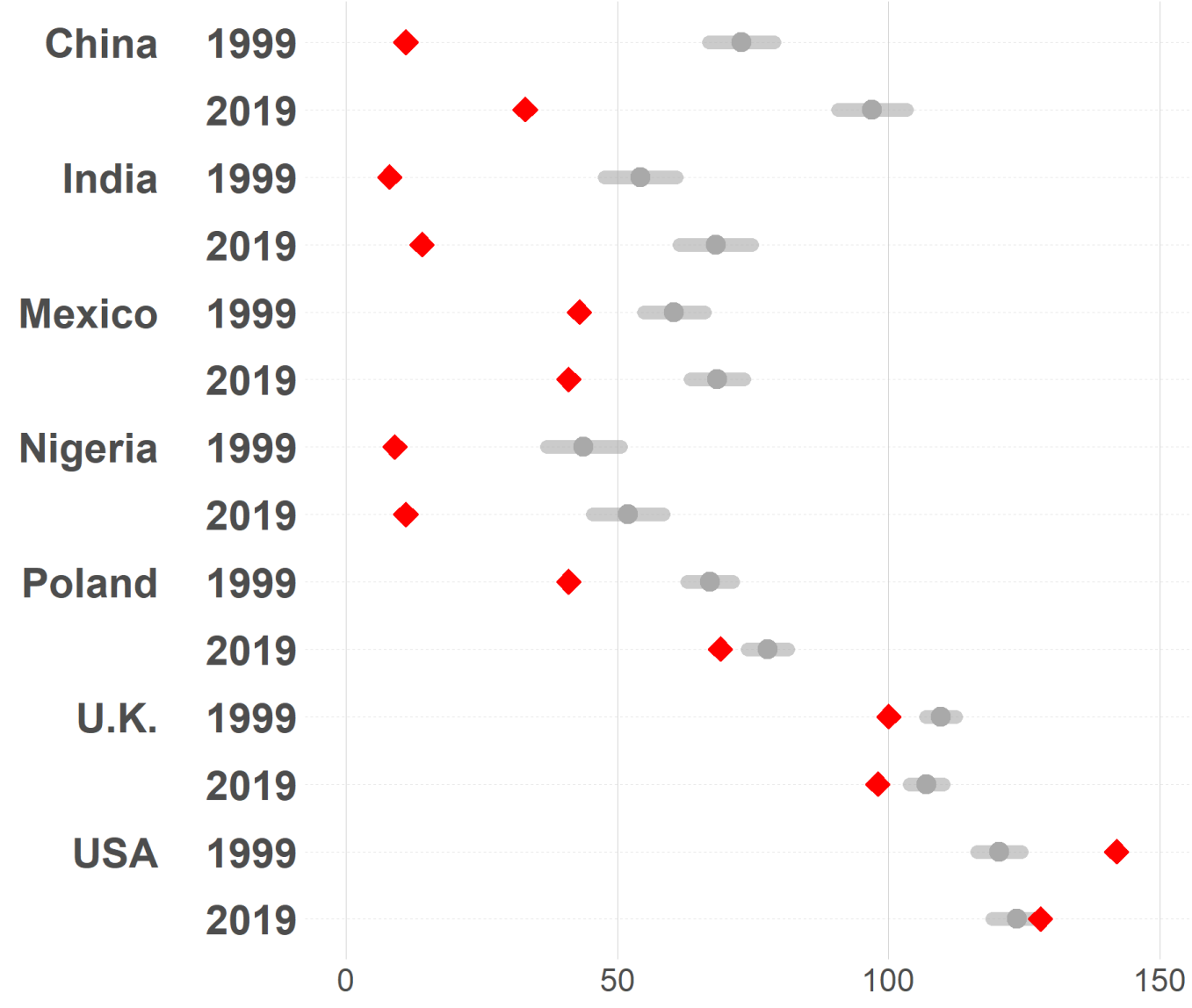


Table 6

One-sample t-tests comparing real and estimate GDP per capita (PPP) in proportion with France's GDP per capita (PPP), in 1999 and 2019, Study 3

\begin{tabular}{|c|c|c|c|c|c|}
\hline \multirow[t]{2}{*}{$\begin{array}{l}\text { Target } \\
\text { country }\end{array}$} & \multirow[t]{2}{*}{ Year } & \multirow[t]{2}{*}{$\begin{array}{l}\text { Actual } \\
\text { proportion }\end{array}$} & $\begin{array}{l}\text { Estimated } \\
\text { proportion }\end{array}$ & \multirow[t]{2}{*}{$\begin{array}{l}\text { Overestimation } \\
\text { extent* }\end{array}$} & \multirow[t]{2}{*}{ Cohen's d } \\
\hline & & & $\mathrm{M}(\mathrm{SD})$ & & \\
\hline \multirow[t]{2}{*}{ China } & 1999 & 11 & $72.88(38.19)$ & 62 & $1.62 * * *$ \\
\hline & 2019 & 33 & $96.97(40.35)$ & 64 & $1.59 * * *$ \\
\hline \multirow[t]{2}{*}{ India } & 1999 & 8 & $54.30(42.25)$ & 44 & $1.10 * * *$ \\
\hline & 2019 & 14 & $68.12(42.75)$ & 54 & $1.27 * * *$ \\
\hline \multirow[t]{2}{*}{ Mexico } & 1999 & 43 & $60.48(35.57)$ & 23 & $0.49 * * *$ \\
\hline & 2019 & 41 & $68.38(31.43)$ & 27 & $0.87 * * *$ \\
\hline \multirow[t]{2}{*}{ Nigeria } & 1999 & 9 & $43.81(43.21)$ & 35 & $0.81 * * *$ \\
\hline & 2019 & 11 & $51.94(41.48)$ & 41 & $0.99 * * *$ \\
\hline \multirow[t]{2}{*}{ Poland } & 1999 & 41 & $67.12(26.77)$ & 26 & $0.98 * * *$ \\
\hline & 2019 & 69 & $77.74(23.95)$ & 9 & $0.37 * * *$ \\
\hline \multirow[t]{2}{*}{ UK } & 1999 & 100 & $109.62(17.63)$ & 9 & $0.55 * * *$ \\
\hline & 2019 & 98 & $106.97(19.74)$ & 9 & $0.45^{* * *}$ \\
\hline \multirow[t]{2}{*}{ USA } & 1999 & 142 & $120.40(26.31)$ & 22 & $-0.82 * * *$ \\
\hline & 2019 & 128 & $123.63(28.84)$ & 4 & $-0.15^{*}$ \\
\hline
\end{tabular}

Note. ${ }^{*}$ France GDP per capita (PPP) in percentage points; $* * * p<.001 ; * p<.05$ 


\section{Study 4 - British People Underestimate the Economic Difference between the UK and Poorer Countries and Overestimate its Improvement over Time}

The objective of this study is to test whether an illusion of convergence underlies people's overestimation of GDP per capita, in another country (United Kingdom), using three different time-points. This study was preregistered at https://aspredicted.org/28X X7J.

\section{Methods}

Participants. We recruited 389 British participants from Prolific, who were paid $£ 0.70$ for this task. Two participants failed the attention check by replying "Yes" to the question "Have you ever been to the planet Jupiter" and were excluded from analyses as preregistered. This exclusion left 387 participants (84 males, 299 females, 4 other; $M_{a g e}=31.67, \mathrm{SD}=$ 9.65).

Procedure. Participants were first provided with a definition of GDP per capita (PPP). Then, participants were presented with three comprehensions checks, which they had to correctly answer in order to proceed with the survey. Participants were shown six countries in randomized order (Brazil, China, India, Mexico, Nigeria, Russia). Per each country, they were asked to estimate the proportion of GDP per capita (PPP) between the UK and the target country, in 1999, 2009, and 2019 on a slider bounded at 0 and 200, as in previous studies.

For instance, for Nigeria in 1999, participants were asked:

For every \$100 of GDP per capita (PPP) in 1999 in the UK, how many GDP per capita (PPP) dollars do you think Nigeria had in 1999 ?

Please reply on this slider. Note that 100 means that Nigeria the United Kingdom had exactly the same GDP per capita (PPP) in this year.

\section{Results and Discussion}


A series of one-sample t-tests comparing the actual and estimated GDP per capita proportions showed overestimation across the board (Figure 4 and Table 7). In sum, this study shows that people overestimate the extent to which developing and middle-income countries are catching up with industrialized countries, and that this is exacerbated by an illusion of convergence which posits that inequality is massively reduced in the past few decades. We wish to highlight how participants stated that GDP per capita (PPP) of China in both 2009 and 2019 surpassed that of the U.K., the largest overestimation in this study. 
Figure 4. Actual and estimated proportion between GDP per capita (PPP) of target country and of the United Kingdom, Study 4. Estimated means and 95\% confidence intervals around the estimation are depicted.

\section{Actual and estimated values}

Ratio of GDP per capita (PPP) of target country and the UK, in given year

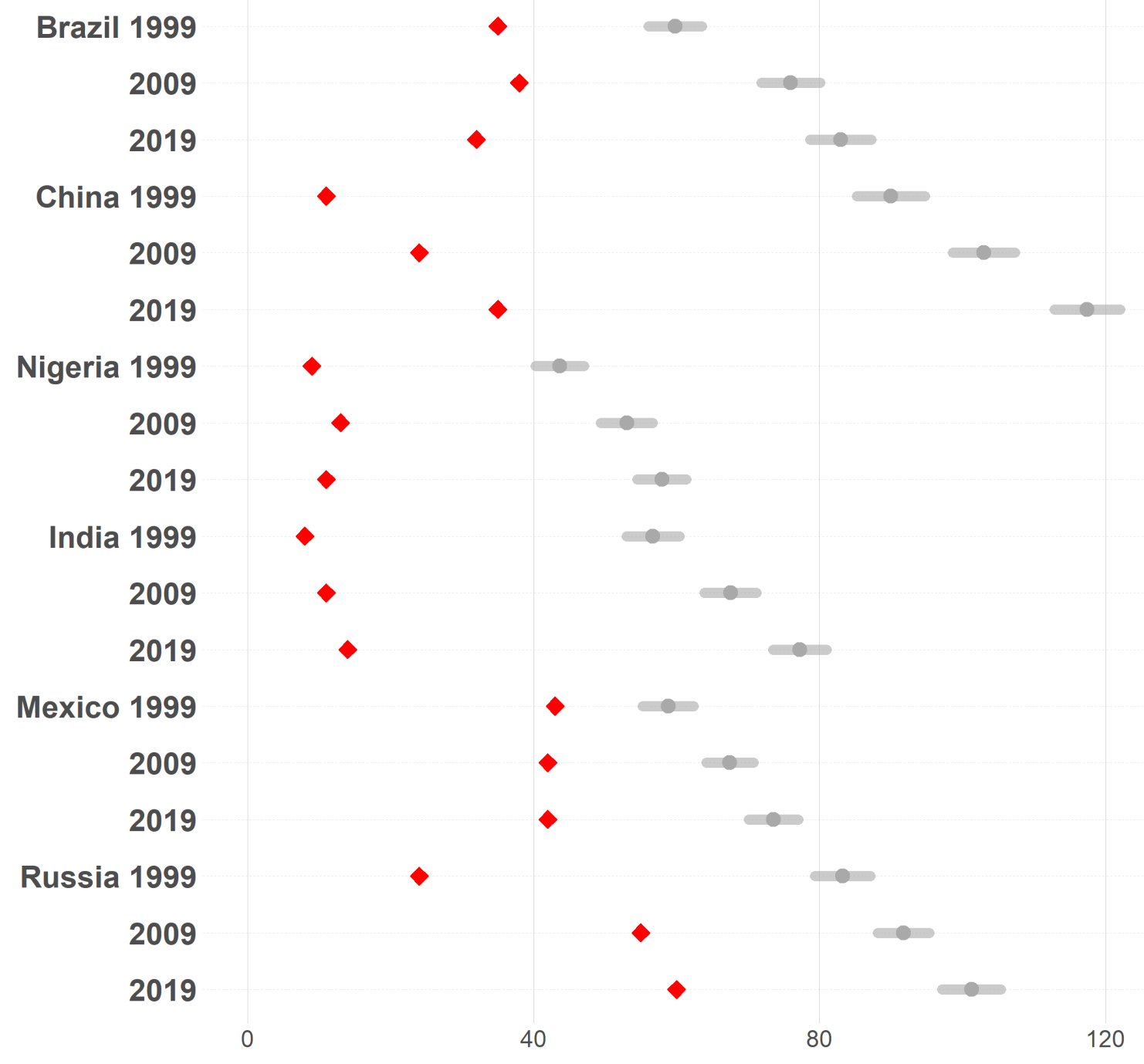


Table 7

Actual and estimated proportion between GDP per capita (PPP) of target country and of the United Kingdom, Study 4

\begin{tabular}{|c|c|c|c|c|c|}
\hline \multirow[t]{2}{*}{ Target country } & \multirow[t]{2}{*}{ Year } & \multirow[t]{2}{*}{$\begin{array}{l}\text { Actual } \\
\text { proportion }\end{array}$} & $\begin{array}{l}\text { Estimated } \\
\text { proportion }\end{array}$ & $\begin{array}{l}\text { Overestimation } \\
\text { extent* }\end{array}$ & Cohen's d \\
\hline & & & \multicolumn{3}{|l|}{$\mathrm{M}(\mathrm{SD})$} \\
\hline \multirow{3}{*}{ Brazil } & 1999 & 35 & $59.80(36.29)$ & 25 & $0.68 * * *$ \\
\hline & 2009 & 38 & $75.98(40.08)$ & 38 & $0.95 * * *$ \\
\hline & 2019 & 32 & $82.96(41.58)$ & 51 & $1.23 * * *$ \\
\hline \multirow[t]{3}{*}{ China } & 1999 & 11 & $90.01(46.34)$ & 79 & $1.71 * * *$ \\
\hline & 2009 & 24 & $103.00(42.45)$ & 89 & $1.86 * * *$ \\
\hline & 2019 & 35 & $117.44(44.79)$ & 82 & $1.84 * * *$ \\
\hline \multirow[t]{3}{*}{ India } & 1999 & 8 & $56.72(35.88)$ & 49 & $1.36 * * *$ \\
\hline & 2009 & 11 & $67.56(35.62)$ & 57 & $1.59 * * *$ \\
\hline & 2019 & 14 & $77.27(36.30)$ & 63 & $1.74 * * *$ \\
\hline \multirow[t]{3}{*}{ Nigeria } & 1999 & 9 & $43.67(33.33)$ & 35 & $1.04 * * *$ \\
\hline & 2009 & 13 & $53.05(35.26)$ & 40 & $1.14 * * *$ \\
\hline & 2019 & 11 & $57.97(33.51)$ & 47 & $1.40 * * *$ \\
\hline \multirow[t]{3}{*}{ Mexico } & 1999 & 43 & $58.84(34.71)$ & 16 & $0.46 * * *$ \\
\hline & 2009 & 42 & $67.46(32.20)$ & 25 & $0.79 * * *$ \\
\hline & 2019 & 42 & $73.55(33.66)$ & 22 & $0.94 * * *$ \\
\hline \multirow[t]{3}{*}{ Russia } & 1999 & 24 & $83.23(37.96)$ & 59 & $1.57 * * *$ \\
\hline & 2009 & 55 & $91.73(35.09)$ & 37 & $1.05 * *$ \\
\hline & 2019 & 60 & $101.27(40.14)$ & 41 & $1.03 * * *$ \\
\hline
\end{tabular}

Note. *UK GDP per capita (PPP) in percentage points; $* * * \mathrm{p}<.001$ 


\section{Study 5 - Overestimating the Economic Standing of Other Countries Correlates with Attitudes towards Aid and Perceived Military Threat}

The objective of this study is to test whether the underestimation of GDP per capita correlates with attitudes towards economic aid from one country to other countries, perceived military threat, and attitudes towards immigration from those countries. This study was preregistered at https://aspredicted.org/1DP_BVC.

\section{Methods}

Participants. We recruited 399 U.S. American participants from Prolific, who were paid $£ 0.60$ for this task. No participants failed the attention check so all participants (105 males, 282 females, 9 nonbinary people, 1 other, 2 preferred not to disclose; $M_{\text {age }}=27.26, \mathrm{SD}=$ 8.45) were included in the analyses.

Procedure. As in previous studies, participants were shown a short definition of GDP per capita (PPP). Then, participants replied to three comprehension checks. They could not continue with the survey until they replied correctly. Then, participants were shown six countries, in randomized order (Brazil, China, India, Mexico, Nigeria, and Russia). Per each country, they were asked to indicate how many GDP per capita (PPP) dollars they thought the target country had in 2019 for every $\$ 100$ of GDP per capita in 2019 in the USA, on a slider bounded at 0 and 200. Then, they were asked three questions per country, all anchored at 1 (not at all) and 7 (very much): "Do you think the USA should send aid to this country?"; "Do you think this country is a military threat to the USA?", and "Do you think it should be easier for people in this country to immigrate to the USA?"

\section{Results and Discussion}

A series of one-sample t-tests comparing the actual and the estimated GDP per capita proportions showed overestimation across the board, and seemingly larger for developing and middle-income countries compared to richer countries (Table 8). This study confirms that 
U.S. Americans overestimate global inequality, and especially the economic standing of China, which they believed has higher GDP per capita (PPP) compared to the USA. Further, we ran a series of correlations between GDP estimation and political attitudes towards each target country (Table 9), finding statistically significant and small-to-medium correlations with attitudes towards aid (negative, meaning that the larger the perceived economic might of a country, the less likely people are to favour sending aid to the country) and perceived military threat (positive, meaning that the more a person perceives a country to be economically equivalent to the US, the more they perceive that country to be a military threat). However, we found no sizeable or statistically significant correlation between overestimation of GDP per capita and attitudes towards immigration from a country (with the exception of China's). Overall, this study shows that GDP per capita estimation correlates with politically important attitudes, including attitudes towards aid and the perception of military threat. We found important heterogeneity both between-measures and between associations of GDP per capita estimation across countries. For instance, for Nigeria we found a strong correlation between military threat and GDP overestimation $(r=.40)$, but for Russia, a very weak one $(r=.01)$, a finding deserving of further exploration. 
Table 8

Overestimation and results of one-sample t-tests, Study 5

\begin{tabular}{lllll}
\hline $\begin{array}{l}\text { Target } \\
\text { country }\end{array}$ & $\begin{array}{l}\text { Actual } \\
\text { proportion }\end{array}$ & $\begin{array}{l}\text { Estimated proportion } \\
\text { M (SD) }\end{array}$ & $\begin{array}{l}\text { Overestimation } \\
\text { extent* }\end{array}$ & Cohen's d \\
\hline Brazil & 23 & $71.82(33.46)$ & 49 & $1.46^{* * *}$ \\
China & 26 & $108.92(40.68)$ & 83 & $2.04 * * *$ \\
India & 11 & $73.67(40.62)$ & 63 & $1.54 * * *$ \\
Mexico & 32 & $66.22(34.10)$ & 34 & $1.00^{* * *}$ \\
Nigeria & 8 & $52.34(38.17)$ & 44 & $1.16^{* * *}$ \\
Russia & 45 & $95.43(36.03)$ & 50 & $1.40^{* * *}$
\end{tabular}

Note. *US GDP per capita (PPP) percentage points; $* * * p<.001$

Table 9

Correlations between GDP estimation and attitudes towards aid and perceived military threat, Study 5

\begin{tabular}{llll}
\hline Target country & $\begin{array}{l}\text { Correlation } \\
\text { between } \\
\text { estimation and } \\
\text { aid }\end{array}$ & $\begin{array}{l}\text { Correlation } \\
\text { between } \\
\text { estimation and } \\
\text { military threat } \\
\text { perception }\end{array}$ & $\begin{array}{l}\text { Correlation } \\
\text { between } \\
\text { estimation and } \\
\text { ease to } \\
\text { immigrate }\end{array}$ \\
\hline Brazil & $-0.11^{*}$ & $0.20^{* * *}$ & 0.01 \\
China & $-0.12^{*}$ & 0.07 & $0.11^{*}$ \\
India & $-0.21^{* * *}$ & $0.16^{* *}$ & 0.09 \\
Mexico & $-0.14^{* *}$ & $0.19^{* * *}$ & -0.01 \\
Nigeria & $-0.19^{* * *}$ & $0.40^{* * *}$ & 0.09 \\
Russia & 0.02 & 0.01 & 0.07
\end{tabular}

Note. $* * * p<.001 ; * * p<.01 ; * p<.05$ 


\section{General Discussion}

The present work shows that Westerners (British and U.S. Americans members of the public, and French students) underestimate global inequality. They believe that developing and middle-income countries have higher rates of car ownership, larger houses, and eat out more frequently than they actually do, both in absolute and comparative estimates. Further, people believe that developing and middle-income countries' GDP per capita is much closer to the developed countries where participants live (the U.S.A., the U.K., and France) than it actually is. We also find evidence in favor of a convergence illusion: participants believed that poorer countries closed the GDP gap very fast in the past thirty years and are on their way to reaching equality with richer countries. Finally, we show that overestimating GDP per capita correlates with attitudes towards aid for other countries and perceived military threat.

The present work provides a first look at perceptions of global inequality by describing what Westerners think of other countries' standard of living, and showing that they vastly overestimate it. This finding advances the literature about perceptions of inequality, which has focused on within-country perceptions (e.g., Kraus et al., 2017; Niehues, 2014). It is especially striking to look at the estimation regarding China's economic standing, which French, British, and U.S. American participants believed was at the same economic level as or richer than France, the United Kingdom, and the USA, respectively. Further, the present work shows that such overestimations are negatively associated with attitudes towards international aid, and positively associated with perceived military threat (but we found little evidence that it correlates with attitudes towards ease of immigration), showing theoretically interesting consequences of such overestimations. It seems that the overestimation of the economic position of a country may stand in the way of increased support for international cooperation. 
This work has practical implications for global economic justice. If Westerners' perceptions of other countries economic standing is so biased, it is unsurprising that little progress has been made towards global income convergence compared to the hopes voiced, among others, by Senator Wherry in 1940 and by several leaders of poorer countries more recently (e.g., United Nations, 2020). Further, it points out that overestimations of other countries' economic standing may go hand in hand with important international attitudes. Perhaps, making economic perceptions more accurate would push rich countries' public opinion towards a higher degree of aid and toward military détente, and in turn, influence their governments.

Future research should survey what people in developing and middle-income countries think of their global standing, both compared to each other and to developed countries. Are their assessments as biased as the ones in richer countries, and if so, in which direction? Further, it is interesting to investigate whether there are methods to reduce global inequality misperceptions or if these are as resilient as misperceptions about the Black-White wealth gap in the USA (e.g., Onyeador et al., 2021). Finally, we have found substantial variation across correlations between overestimation of the economic standing of other countries and attitudes regarding aid and perceived military threat (for instance, for Nigeria we found a strong correlation between perceived military threat and GDP per capita overestimation, $r=$ .40 , but for Russia, a very weak one, $r=.01$ ). Future research may investigate the reasons behind this heterogeneity.

Ultimately, these findings document Westerners' profound misunderstanding about global economic disparities and may help explain the persistence of global inequality and conflict. 


\section{References}

Bren d'Amour, C., Pandey, B., Reba, M., Ahmad, S., Creutzig, F., \& Seto, K. C. (2020).

Urbanization, processed foods, and eating out in India. Global Food Security, 25(November 2019), 100361. https://doi.org/10.1016/j.gfs.2020.100361

Callaghan, B., Harouni, L., Dupree, C. H., Kraus, M. W., \& Richeson, J. A. (2021). Testing the efficacy of three informational interventions for reducing misperceptions of the Black-White wealth gap. Proceedings of the National Academy of Sciences of the United States of America, 118(38), 1-8. https://doi.org/10.1073/pnas.2108875118

Chambers, J., Swan, L., \& Heesacker, M. (2014). Better Off Than We Know: Distorted Perceptions of Income Inequality in America. Psychological Science, 25(2), 613-618. https://doi.org/10.1177/0956797613504965

Cruces, G., Perez-Truglia, R., \& Tetaz, M. (2013). Biased perceptions of income distribution and preferences for redistribution: Evidence from a survey experiment. Journal of Public Economics, 98, 100-112. https://doi.org/10.1016/j.jpubeco.2012.10.009

Eriksson, K., \& Simpson, B. (2013). The available evidence suggests the percent measure should not be used to study inequality: Reply to Norton and Ariely. Judgment \& Decision Making, 8(3), 395-396.

Fernández-Albertos, J., \& Kuo, A. (2015). Income Perception, Information, and Progressive Taxation: Evidence from a Survey Experiment. Political Science Research and Methods, 1-28. https://doi.org/10.1017/psrm.2015.73

Gimpelson, V., \& Treisman, D. (2018). Misperceiving inequality. Economics and Politics, 30(1), 27-54. https://doi.org/10.1111/ecpo.12103

Kantar. (2021). Food 360. Kantar.Com. https://www.kantar.com/fr/expertises/marketintelligence/nos-etudes-collectives/food-360

Kraus, M. W., Hudson, S. T. J., \& Richeson, J. A. (2020). Framing, Context, and the 
Misperception of Black-White Wealth Inequality. Social Psychological and Personality Science, 3(6).

Kraus, M. W., Rucker, J. M., \& Richeson, J. A. (2017). Americans misperceive racial economic equality. Proceedings of the National Academy of Sciences of the United States of America, 114(39), 10324-10331. https://doi.org/10.1073/pnas.1707719114

Milanovic, B. (2021). After the Financial Crisis: The Evolution of the Global Income Distribution Between 2008 and 2013. Review of Income and Wealth, 0. https://doi.org/10.1111/roiw.12516

Niehues, J. (2014). Subjective Perceptions of Inequality and Redistributive Preferences: An International Comparison. In IZA Bonn working papers. file:///Users/orhantorul/Downloads/Inequality_Perception_Discussion_Paper_Judith_Ni ehues.pdf

Nolan, A. (2010). A dynamic analysis of household car ownership. Transportation Research Part A: Policy and Practice, 44(6), 446-455. https://doi.org/10.1016/j.tra.2010.03.018

Norton, M. I., \& Ariely, D. (2011). Building a Better America--One Wealth Quintile at a Time. Perspectives on Psychological Science, 6(1), 9-12. https://doi.org/10.1177/1745691610393524

OECD. (2021). OECD Better Life Index. Oecdbetterlifeindex.Org. https://www.oecdbetterlifeindex.org/topics/housing/

Onyeador, I. N., Daumeyer, N. M., Rucker, J. M., Duker, A., Kraus, M. W., \& Richeson, J. A. (2021). Disrupting Beliefs in Racial Progress: Reminders of Persistent Racism Alter Perceptions of Past, But Not Current, Racial Economic Equality. Personality and Social Psychology Bulletin, 47(5), 753-765. https://doi.org/10.1177/0146167220942625

Pew Research Center. (2015). Car, bike or motorcycle? Depends on where you live. Pewresearch.Org. https://www.pewresearch.org/fact-tank/2015/04/16/car-bike-or- 
motorcycle-depends-on-where-you-live/

United Nations. (2020). World Leaders Adopt Declaration Promising Safer, More Resilient World for Future Generations, as General Assembly Marks United Nations SeventyFifth Anniversary. Un.Org. https://www.un.org/press/en/2020/ga12267.doc.htm

World Bank. (2019). GDP per capita, PPP (current international \$). Data.Worldbank.Com. https://data.worldbank.org/indicator/NY.GDP.PCAP.PP.CD?locations=FRUS\&view=chart

World Bank. (2021). Gini index (World Bank estimate) - South Africa. Data.Worldbank.Org. https://data.worldbank.org/indicator/SI.POV.GINI?locations=ZA 